\title{
บUsisersily
}

\section{How can the University Library Better Meet the Information Needs of Research Students? Experiences from Ulster University}

Delaney, G., \& Bates, J. (2018). How can the University Library Better Meet the Information Needs of Research Students? Experiences from Ulster University. New Review of Academic Librarianship, 24(1), 63-89. https://doi.org/10.1080/13614533.2017.1384267

Link to publication record in Ulster University Research Portal

\section{Published in:}

New Review of Academic Librarianship

Publication Status:

Published (in print/issue): 30/01/2018

DOI:

10.1080/13614533.2017.1384267

\section{Document Version}

Author Accepted version

\section{General rights}

Copyright for the publications made accessible via Ulster University's Research Portal is retained by the author(s) and / or other copyright owners and it is a condition of accessing these publications that users recognise and abide by the legal requirements associated with these rights.

\section{Take down policy}

The Research Portal is Ulster University's institutional repository that provides access to Ulster's research outputs. Every effort has been made to ensure that content in the Research Portal does not infringe any person's rights, or applicable UK laws. If you discover content in the Research Portal that you believe breaches copyright or violates any law, please contact pure-support@ulster.ac.uk. 


\title{
How can the University Library better meet the information needs of research students: Experiences from Ulster University
}

\begin{abstract}
This article investigates academic library needs of doctoral students. The study identifies PhD students' information literacy training needs and explores current levels of library engagement, barriers to use and gaps in existing services. First year PhD students at Ulster University were surveyed and interviews were undertaken with three students. Findings show that just over half the respondents start their research from the Library's e-journal interface or library databases and these resources are also their main research tools. Little use was made of social media or apps. Students' ability to correctly identify different source types within a reference did not match the confidence they expressed in their own abilities, and two thirds were not aware of basic e-book capabilities. However over $90 \%$ of the respondents strongly agreed that the university library service was essential for their research. The article concludes with a number of recommendations on improving library services for PhD students.
\end{abstract}

\section{Key words:}

Information literacy; Researchers; Students; University libraries; Users

\section{Introduction}

Despite a wealth of research about the information practices of undergraduate students, few studies have concentrated on doctoral students as a discrete group. Catalano (2013) undertook a meta-synthesis of the research literature on graduate students' informationseeking behavior and found only 11 studies published between 1997 and 2012 that focused specifically on the information-seeking behaviour of doctoral or post-doctoral students (the majority of which were qualitative studies). This lack of evidence has had an impact on how academic libraries market services to doctoral students and indeed on what services are offered (Fleming-May and Yuro, 2009; Harris, 2011; RIN and RLUK, 2011). Spezi (2016) builds on the work by Catalano (2013) with a review of the literature on doctoral students' information-seeking behaviours focusing in particular on literature published between 20102015. Her review emphasises the changes in research practices, particularly with regard to online behaviours.

The work and nature of the academic library is becoming less visible (British Library and JISC, 2012), and with profound shifts in research pedagogy (Dowling and Wilson, 2017), there is a threat that the intrinsic value of the library may not be appreciated by a generation of researchers who increasingly engage solely online (RIN and RLUK, 2011). Jubb and MacColl (2011) illustrate how hard it can be for libraries to get the attention of researchers. While academic libraries typically provide some information skills training for doctoral students, many researchers think these are focused primarily on collection management and services to undergraduates, rather than on the needs of the research community (Research Information Network, 2011). Across UK libraries, and indeed elsewhere, the absence of library-driven research information skills training or assessment is conspicuous given the high priority attached to graduate skills training by UK Research Councils (Corrall, 2008). 
The aim of this study at Ulster University, Northern Ireland, was to investigate the information practices and research needs of doctoral students in order to provide insight into how university library services might better communicate with them, to identify possible barriers to full library engagement, and potential 'zones of intervention' (Kuhlthau, 1994; Barrett, 2005; Fleming-May and Yuro, 2009) for assisting them. In September 2013, the Ulster University Library Service Research Working Group met with the Heads of Graduate Schools, and while the Heads were complimentary of the library service provided, the biggest concern was lack of communication between the library and research students, and misconceived graduate perceptions that everything was available for the researcher on the Internet, and therefore there was no need of physical library services and interventions. Like many universities, Ulster University provides a generic library induction regarding services for doctoral students as well as one-to-one training sessions when requested by an individual. Doctoral students also complete Vitae tutorials, but at present no contributions from the library service are embedded or credit-bearing.

\section{Literature review}

\section{Information behaviours of research students}

It is important to acknowledge that doctoral students are a discrete user group within academic libraries and to recognise their 'distinctive researcher identity' (Petch et al., 2016) and to use this to shape how the library responds to their needs. With doctoral research increasingly done online (Vezzosi, 2009), academic libraries need to ensure they are creating opportunities and tailoring their services to best meet the needs of this stakeholder group.

Doctoral students use search engines as their predominant search tools in research (Drachen et al., 2011; British Library and JISC,2012; Catalano, 2013), and the use of Google Scholar is prolific (Cothran, 2011; Drachen et al., 2011). However, evidence shows that graduates do not even search those well (Catalano, 2010). Use of the library for research students is at critical juncture. Often low use of authoritative library resources is driven by a lack of knowledge about services and research databases (Gibbs et al., 2012). Other reasons for avoidance included the belief among students that librarians lack the expertise necessary, or that students are self-taught when it comes to library skills, and they do not want to appear inept to supervisors or colleagues (Rempel, 2010).

Fleming-May and Yuro (2009) found that users were highly skeptical of services that may appear inefficient and irrelevant to them directly. Training in a new tool or system can be perceived as a 'time sink' unless its immediate utility is apparent (Sadler and Given, 2007; Rempel, 2010). As might be expected, knowledge of services ties into increased use (Catalano, 2013). British Library and JISC (2012) found that technologies were only readily taken up if they proved easy to understand and could readily be absorbed into current practices, and $40 \%$ cited that a new tool would be used if recommended by their supervisor (Carpenter, 2012). Carpenter's study shows that information literacy does not improve with wider access to technology, and that Google commands the same universal influence across all disciplines (Carpenter, 2012). Carpenter also found that researchers prefer face-to-face 
training and that generic training content, not tailored to their subject matter is generally considered ineffective. Many students were unaware of the library's contribution to their online content and access. For example, access to the library services ranked $6^{\text {th }}$ in importance of service, yet subscription to e-journals ranked $1^{\text {st }}$ in terms of importance. Therefore, there is a clear incongruence between critical resources and recognition of the source of resources (British Library and JISC, 2012). Similarly, in a study by Bøyum and Aabø (2015) it was apparent that PhD students initially asserted that they did not use the university library as they were assuming this to mean engagement with physical library facilities, whereas it transpired they were 'heavy users' of online library services.

Prior experience, their reasons for undertaking the doctorate and their learning environment all influence students' interactions and dealings with information (Green, 2010). Rempel (2010) found that students need more support during their earlier stages of study. As the student travels the research journey he/she builds up their knowledge and expertise, important contacts and information sources. Other people, particularly academic staff (professors, supervisors, faculty advisers) also play an important part as graduate students seek their advice, particularly at the start of the research process (Catalano, 2013; George et al., 2006).

The relationship between information literacy and research has been explicitly expressed in the Researcher Development Framework (Vitae, 2010), a tool for supporting the career development of researchers. Within the framework, information literacy is characterised as "comprising knowledge, skills, and competencies required by researchers for the effective handling of research information and data" (Vitae, 2010).

A case study of needs analysis for information literacy provision for research at University College Dublin (Patterson, 2009) found that the assumption that because students had reached $\mathrm{PhD}$ level they were competent in information seeking does not stand. Korobili et al., (2011) found that information literacy was deemed overall poor to average in their graduates, which the authors attributed to lack of faculty co-operation and low student attendance at instructional sessions. Low self-efficacy may also be a significant factor in accounting for the over-reliance on familiar information sources identified early in the research process (Patterson, 2009). Students also experience personal challenges with information overload etc. and to ease this may pursue a pattern of following up citations in already located materials (citation chaining) but this does not ensure comprehensiveness (George et al., 2006). Harrington (2009) demonstrated haphazard, confused and inconsistent research methods among doctoral research students. Research has shown that citation error rate does not improve with progression through the years, and Fleming-May and Yuro (2009) found a strong correlation between library anxiety and citation errors.

There is minimal understanding of information literacy among academic administrators. The perpetuated experience (osmosis gap) is that faculty learned their skills by a process of trial and error and have little memory of what it is like to be a neophyte student, and therefore cannot appreciate the current information overload experienced by many students. Bury (2011) has provided corroboration that faculty believe students improve their research processes ability over time despite the lack of training. 
Information literacy by osmosis thus remains an untested belief (Badke, 2012). By its nature, doctoral pedagogy requires that candidates be self-directed and intellectually independent. The most valued, most frequent and influential academic contacts for doctoral students are with their doctoral supervisors, and this is where librarians must build confidences (British Library and JISC, 2012). The role of supervisor is seen as focused on imparting disciplinespecific knowledge, but they are less inclined to convey high-level information skills. They generally do not focus on instruction and advising on either their students' information needs or literature reviewing (Green and Macauley, 2007), and this can be seen as a possible expanding role for librarians. The communication difficulties with faculty have been attributed to the librarian's lack of research background and a belief that librarians lack an appreciation of the exertions and methodology of research (Fleming-May and Yuro, 2009). However, preconceptions of the library's role in a purely liaison model are outmoded and library research assistance within the disciplines in helping with managing workflows and processes rather than just bibliographic instruction are developing (Jaguszewski and Williams, 2013). The need for greater collaboration between faculty and academic librarians is underlined in the dissertation work of Bishop (2015). In relation to the lack of librarian research expertise, Daland (2013) emphasises the importance and benefit of informal collaboration and discussion between library staff and doctoral researchers as this can enable learning to take place for both parties. Madden (2014, p104) also found evidence of two-way learning in a specific taught postgraduate researcher module in Information Literacy: "A direct benefit of the module is that researchers develop an understanding of the potential of the library, and its key contacts for research support. Likewise, librarians teaching the course gain a greater insight into the work of PhD students, their information practices as researchers, and how they cope in the first year."

Diversity within the doctoral student community has many implications for the library service. New doctoral students are a varied group and previous educational experience varies. International students typically make up a significant part of the doctoral body. Many research students might not be aware of specialist tools, while others have excellent information finding and handling skills. Doctoral students who do not enter the programme directly from research-based undergraduate or masters' programmes are assumed to lack expertise in dealing with this complex information environment (Macauley and Green, 2010). Equally graduates are often presumed to enter with the required skills for managing information and knowledge (Green, 2010). However, as Badke (2012) emphasises, it is problematic to assume at graduate level that students have received information literacy instruction at undergraduate level or will learn information literacy skills independently.

In Fleming-May and Yuro's (2009) focus groups, cultural differences in the students' experiences of libraries and librarians played a key role in influencing students' informationseeking processes. Several international students did not know the librarians' role and preferred to email friends with difficulties. Liu and Winn's (2009) study of a group of Chinese research students and their use of the library showed they did not take full advantage of the services and resources partly due to limitation of their English language. The students were not familiar with many key library terms and because of cultural differences they tended not to seek help. Orientation and skills classes are usually timetabled at the beginning of the semester when students have a lot going on, in the early weeks of their candidature when they are immersed in different things and perhaps international students have not yet enrolled. 


\section{The role of the library and library interventions}

Seen primarily as a 'purchasing agent' by established researchers and faculty (Housewright et al., 2012), and with lack of researcher engagement an area of increasing misalignment (Hernon and Mathews, 2013), university libraries should be actively seeking out new roles and responsibilities in order to fully engage with researchers (Kroll and Forsman, 2010; Delaney and Bates, 2015), and services for researchers should be emerging and expanding as universities enhance their research profile (Auckland, 2012). Research Libraries UK has established that a shift is needed in the librarians' remit to play a greater role in the research process, and actively support the evolving information needs of researchers (Auckland, 2012). Bussell et al. (2016) emphasise that research instruction needs to be provided to "graduate students in formats that can be accessed or attended when needed, while at the same time focusing extra effort on marketing to key groups that have been shown to have lower confidence in various research skills."

The Research Information Network (RIN) model addresses where libraries will have the greatest impact, which is by providing support within an institution. Research outcomes and end benefits include tangible items such as: "Increased visibility of research, better research management and improved coordination as well as intangible benefits like more satisfied researchers, increased potential readership, and more motivated researchers" (RIN/RLUK, 2011, p19).

Universities have understood the requirements to provide research skills to doctoral students often with core mandatory modules and a selection of optional training courses (BL/JISC, 2012). Generally however the training is fragmented and implemented by different departments, and the commitment by students to library training is poor with $33 \%$ of students in the Researchers of Tomorrow cohort never using library support at all (British Library and JISC, 2012).

With a changing research environment comes new training needs - historically graduate research support has been developed as an extension of undergraduate programmes and not based on the specialist needs of the community (Macauley and Green, 2007). Information literacy instruction is well represented at undergraduate level, however, at a postgraduate level it is less evident (Corrall, 2012). At this level, information literacy is implicit rather than explicit (Patterson, 2009). The Research Information Network (2011) points to the lack of assessment of researchers' training needs, recommending that the library should adopt more systematic and innovative approaches to identifying and assessing the needs of researchers to enhance their information-related skills and competencies.

Green (2010) suggests that libraries create point of need opportunities and that an understanding of the entire dissertation process would help librarians in their service delivery. She mapped results onto Association of College and Research Libraries' (ACRL) standards. The role of teaching faculty in delivering information literacy guidance emerged as a dominant finding. Faculty were often the source of information regarding library research, directing which databases etc. to use and reinforced the important role of faculty in 
teaching not just about subject content and the research process but also identifying library resources.

Researchers of Tomorrow confirm a need for new, ratified research services. Much librarian / researcher interaction takes place on an ad hoc basis. These sessions mostly focus on information seeking and citation of sources, based on an assortment of services that the library itself provides. However there is much less coverage of newly needed competencies - such as, evaluating, organising, and communicating information, or key underpinning issues such as workflow support, information management and archiving (Allan, 2010).

Monroe-Gulick and Petr (2012) found that in order to provide an appropriate level and focus of library instruction and support for new graduate students, programming should be based on information that identifies incoming strengths and deficiencies from evidence-based auditing. Loughborough University and Warwick University are two examples of UK universities that have produced diagnostic tools to allow postgraduates to reflect on their information searching abilities and other research competencies and attend appropriate courses for their information literacy needs. Loughborough, by mapping their services against the Research Lifecycle, aid students to identify interventions best suited to their research stage, and have gone beyond searching and retrieving information by offering assistance with publication strategies, current awareness training and social media training. This type of instruction in relevant research topics and tools can help the researcher utilise a more contemporary, authentic research experience. Research support going beyond traditional provision and embracing new forms of scholarly communication is increasing. For example, University College Dublin provides tutorials on current awareness training and using social media for research, and London School of Economics have embedded information literacy within the doctoral programme, providing a six week credit bearing course in information literacy for research. Warwick's diagnostic tool, while targeting Masters' students primarily, allows for the graduate student to identify their own deficiencies and offers interventions and training based on those articulated needs. This helps the user take ownership of his/her own needs analysis and find the value in the library support. However there remains the potential for disparity between perceived and actual needs with graduate students in information literacy training, nonetheless, awareness of deficiencies is the foundation for a more pertinent learning experience (Jackson, 2013).

Information literacy instruction from the library at present is 'short-term remedial'. To equate information literacy with teaching students library instruction is short-sighted, and this misconception is prevalent (Andretta, 2012). Familiarity with the nature of the doctoral process would give the library insight about opportunities for providing services and assistance to those enrolled. Fleming-May and Yuro (2009) found that working with academic staff to increase awareness of library resources would benefit graduates who rely heavily on and are influenced by their supervisors (Monroe-Gulick and Petr, 2012). As seen in the examples of interventions discussed above, approaches taken by academic libraries to support research students also need to acknowledge and incorporate web 2.0 developments: "In order for IL at postgraduate level to remain relevant, its models should reflect the new principles of research work and alternative forms of scientific communication" (Špiranec and Zorica, 2012: 13). 
The literature demonstrates a need for a reconceptualisation of library roles and information literacy interventions at doctoral level. It shows how graduates use, and do not use, the academic library given changes in the research environment, practices and tools. The literature also highlights that competency should not be assumed from confidence, that there is an increasing need to respond to the diversity of the doctoral student population, and supervisor buy-in to library services is crucial.

Doctoral degrees can vary greatly, however the major component relevant to all is the literature review. This is where the greatest incidence of student engagement with library resources and services occurs (Fleming-May and Yuro, 2009).

\section{Methodology}

This study focuses on first year doctoral students as it is typically during their first year that they undertake a literature search and review. The research questions were:

- What are first year doctoral students' current use and experience of the university library service?

- How do they perceive the library's role in the research process and what additional services would they like to see?

- How can the library engage more effectively with doctoral students?

There were two phases to data collection. Firstly, a survey by online questionnaire was developed to elicit information from as many of the first year doctoral students as possible in relation to their experience and use of the library (at the time of data collection in 2014 there were around 180 first year doctoral students at Ulster University). The second phase involved a small number of semi-structured interviews which enabled themes that had emerged from the survey to be discussed in more detail.

\section{Phase 1: The questionnaire}

The survey focused on students' perceptions of their library research needs; their preferences for learning about library research support and the library's role in their research. Early questions were short, succinct and easy to answer as a means of encouragement to completing the questionnaire. They then lead into wider behavioural questions and those with institutional scope, such as what skills and tools doctoral students might need for their work/ library resources are beneficial. Finally questions were asked to determine attitudes to library instruction and the key drivers and constraints of their work. A copy of the questionnaire can be found in the appendix.

The questionnaire was piloted to three PhD students. It was also presented to two academic subject librarians at Ulster University, and amendments were made on their suggestions. Feedback included issues on wording, readability, format and length.

The survey was live from March to April 2014. Initially the questionnaire was distributed to the Heads of the Graduate Schools at Ulster University to distribute among doctoral supervisors, and in turn to their students. This method hoped to give a certain authority to the questionnaire, and distinguish this particular questionnaire from routine surveys circulated among students, and prevent survey fatigue. The questionnaire was also 
promoted on different social media platforms throughout the University in the hope of achieving an optimal response rate. A total of 61 questionnaires were completed from a population of 180 , with a response rate of $34 \%$.

\section{Phase 2: Interviews}

In the survey, respondents were invited to participate in the interview process and three volunteers were selected. Interviews took place in June 2014. The interviews were primarily concerned with open-ended questions that allowed the interviewee to speak freely about their information behaviours and the role of the library in their research.

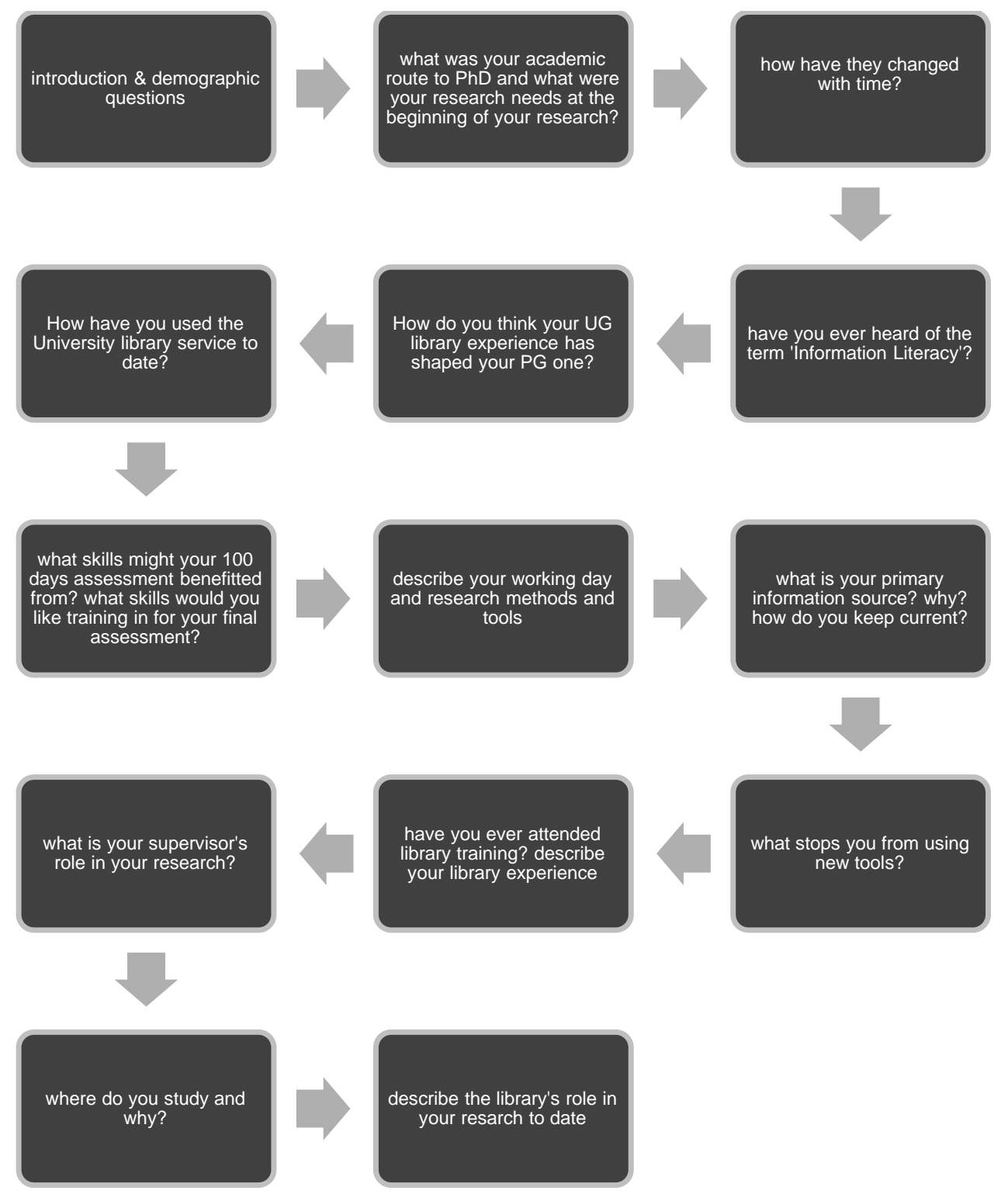

Figure 1: The interview guide (Delaney, 2015)

\section{Findings and discussion}

The results are presented with key findings listed followed by a discussion of emerging themes: 
- current use of library services and facilities;

- information seeking behaviour and the use of information resources;

- the library as a place for study;

- perception of the library's role in the research process;

- assessment training, unmet needs and new services;

- social media and current awareness

- developing relationships between doctoral students and the library; and

- the relationship between profile and needs.

Key findings

- The majority of PhD students at Ulster University (77\%) are not digital-natives.

- Two thirds (66\%) are coming either directly from undergraduate studies or with at least three years absence from scholarship (34\% come directly from postgraduate study). Forty-three percent had not written an academic assignment for one year prior to submitting their research proposal.

- Eighty-seven percent of respondents had undertaken some form of library training with $91 \%$ of these finding it useful to their research. Preferred methods for library training were either online workshops or one-to-one subject librarian consultations.

- Just over half of first year doctoral students (52\%) start their research from the Library's e-journal interface or databases and these resources are also their main tools for research.

- E-journals, books and e-books are critical resources for Ulster University students. However, $68 \%$ were not aware of basic e-book capabilities.

- Despite expressing confidence in their research literacy competencies, $40 \%$ identified a chapter in a book incorrectly, $40 \%$ an online journal article incorrectly, $13 \%$ a blog citation incorrectly, and $10 \%$ identified a journal reference incorrectly.

- Students articulated a lack of familiarity and competence in finding grey literature and copyright and intellectual property issues.

- There is little evidence of use of social media or apps to gather, manage or disseminate research among the respondents - three quarters $(74 \%)$ did not use social media in their research.

- Half of the PhD students surveyed (50\%) were unaware of the Library's special collections, with $3 \%$ citing that they might have used them if they had been aware.

- The main constraint to accessing research literature concerned access restrictions for online content.

- Ninety-one percent of respondents strongly agreed that Ulster University's library service was essential for their research, with $88 \%$ strongly agreeing or agreeing that the library provides for all of their information needs.

\section{Current use of library services and facilities}

Overall, satisfaction with university library services was high. The majority of first year doctoral students had used the library service in order to facilitate access to other libraries' collections, and only $16 \%$ of students were unaware of these facilities. As per the RLUK/RIN (2011) study the respondents relied heavily on secondary published sources (66\%). Fifty 
percent of respondents were unaware of the Library's Special Collections, which raises questions for marketing these resources to the $\mathrm{PhD}$ researcher community.

Library training or library-led interventions had high attendances, with $74 \%$ attending a library induction/welcome, $68 \%$ attending a RefWorks session and $42 \%$ attending a subject librarian's consultation. Only $13 \%$ had not attended any library training at all. Of those who did attend, $91 \%$ deemed the training useful and were very enthusiastic about staff support. Of those who did not attend any library interventions the perception of not needing further training, an unawareness of library-facilitated training and reliance on their supervisor's help were prevalent.

With regard to seeking information and resource advice, all of the interviewees explained that they used their peers and supervisors to assist with their research needs and in procuring information unavailable from the University library. Dependence on supervisors for all types of support dominated the study. Blummer (2009) concluded that working with academic staff to increase awareness of library resources would benefit graduate students who are heavily influenced by suggestions of faculty as these researchers will potentially become faculty of the future and the cycle will continue to repeat.

While students believed the library's online resources are critical for their research, $16 \%$ of respondents stated that they believed that the library did not have the expertise needed by them, or that "Most things I need are online" or " there is no real need for libraries at this level'.

Jackson's (2013) report found that students consistently overestimate their information skills which leads them to avoid attending training. This is a lack of awareness that leads to overconfidence. The survey incorporated a simplistic diagnostic test which suggests a mis-match between self-assessment and ability. Ninety-two percent of users believed themselves to be fairly/ very confident in reference citing; $86 \%$ of users believed themselves to be fairly/ very confident in plagiarism and academic integrity awareness, and $64 \%$ of users thought they were fairly/ very confident in the use of e-books. Of the four simple citation recognition quizzes, $10 \%$ of respondents identified the first the citation incorrectly, $40 \%$ identified the second citation incorrectly, $40 \%$ identified the third citation incorrectly and $13 \%$ recognised the fourth citation incorrectly. On average $26 \%$ of respondents answered the citation questions incorrectly. In another question, when asked to distinguish which of the answers defined plagiarism, $20 \%$ of respondents got the answer wrong and when questioned about e-books $55 \%$ of respondents incorrectly answered the question.

These research students seem unaware of their deficiencies, and while they appreciate the library as an information provider, they appear less likely to value library training. The short test included in the questionnaire suggests that students' over-confidence in ability could be a barrier to their engagement with training interventions. Learning by osmosis is not a reliable pedagogy.

Similarly to Kroll and Forsman (2010), the survey respondents had no perception of the huge internal transformation most libraries have undergone in the conversion to digital access; they do not realise what expertise librarians have to offer and are uninformed about services offered. A fifth (20\%) rarely or never visited the physical library, with $100 \%$ of students 
accessing the online library at least a few times a month, if not a few times a day. The dominance of online resources and its semblance with the library is articulated primarily by the importance the respondents attached to particular resources.

\section{Information seeking behaviour and use of information sources}

E-journals were significant as the most frequent information source used by $36 \%$ of doctoral students surveyed. Students' main go-to resource was the library's e-journal interface, with $30 \%$ using it as the starting point for their literature searching. The library's databases followed with $16 \%$ of the population using these as a basis for their research with Google/Google Scholar following at $14 \%$.

Most students expressed access to credible, current content as a reason for using librarypurchased content, with some explaining that having used the databases and/or e-journals they would then employ citation-chaining to widen their search. It was also noted by a few respondents that the databases would provide an initial search which they would then extend to encompass Google Scholar or vice versa. Library links within Google Scholar were noted but the majority of those using Google or Google Scholar were doing so because it was easy to access, convenient, easy to use and fast. One researcher remarked that Google covered 'everything'. They could check out an author's biography, conferences etc. and found the library's catalogue to be too inhibiting. One first year PhD student cited Wikipedia as an information source to get "a basic understand before finding associated papers".

This study did not find an over-reliance on Google with many of the respondents rationalising that library resources provided credible content, which was prioritised over Google's ease of access and convenience. This reflects a research maturity where instant information gratification cannot compete with credible content.

The main constraint for their research was perceived to be limitations imposed by electronic devices or licencing restrictions. Length of time for ILL requests and unavailability of articles outside what the University subscribed to proved to be the biggest challenges to date for these individuals. As previously mentioned access to content would be sought through supervisors and peers where it could not be accessed through the library.

\section{The library as a place for study}

The majority of students used their University office as their main place of study (53\%), with working from home following at $32 \%$. The respondents believed that by working in the office they set a good work routine and could use their peers for advice. They also mentioned that it was important that their supervisor saw them at the research office, where they could interact with colleagues and increase their profile. A few students mentioned that being able to study from home was only made possible by the access they had to online content. They found working from home quieter, with less distraction and they had all their resources to hand. It also suited their preferred hours of working, usually at night.

It was unsurprising that given research students at UU are allocated their own office space on campus, that only $13 \%$ used the University library as a place of study. The main reason for not using the physical library more was the perceived notion that everything was 
available online. Lack of dedicated research student space, noise and limited amount of terminals were also mentioned as barriers. Commuting distance for many students was also commented on. Quite a few students identified borrowing text books but were frustrated by borrowing capabilities and some still cited being unfamiliar with the library facilities.

\section{Perception of the library's role in the research process}

Likert-scale questions were used to determine how important library resources were to the students' research. Respondents cited access to the library's online resources, subject librarian support, and the library's access to other libraries, among the top resources needed for their research (with $92 \%, 73 \%$ and $70 \%$ respectively believing these products or services to be extremely or very important).

Ninety-one percent regarded the University Library as essential for their research, with $80 \%$ agreeing they could find any information they needed through the library service. When asked specifically to express the University Library's role in their research, $92 \%$ of respondents spoke of journal access being critical to their research, and some respondents took this opportunity to acknowledge their subject librarians and Reworks training, with 16\% citing access to a librarian and $19 \%$ attending RefWorks training as being critical to their research

These results are broadly similar to the findings of the 2012 UK survey of academics (Housewright et al., 2013), which included academic staff from Ulster University: $45 \%$ of academics surveyed described themselves as very dependent on the university library for research. They primarily identified the library as a purchaser of much needed resources $(90 \%$ of those surveyed) and focussed less on other roles. This signifies an inherent need for the library to promote and show value in its other services. These early-career researchers have equated the library service with online access and content, which will in time be passed on to their students. Interviewee A in particular revealed intriguing observations on how the research landscape and the library service had changed in the ten years between starting her first and second PhD. She believed her interaction with the library to be more ten years ago because the exploitation of online resources has meant that her interaction is now less. In essence the library's seamless delivery of online resources has resulted in potential disengagement with researchers.

\section{Assessment training, unmet needs and new services}

Secker and Macrae-Gibson (2011) emphasise there is a need to promote training and to differentiate the support for doctoral students and researchers from support offered to undergraduates or Masters students.

The survey identified two specific signposts in the doctoral candidates' first year: The 100 days Viva/ initial assessment and their end of year assessment. When asked which types of training might have been beneficial for the 100 days assessment, $50 \%$ of respondents referred to 'Presenting Skills'. 'Academic writing skills' and 'writing a literature review' were also popular ( $41 \%$ each). 'Consultation with a subject librarian' (23\%) was also mentioned as likely to have been beneficial, but unfortunately no statement was made as to why a 
consultation was not sought. Eighteen percent of respondents indicated that they had no need for further training.

A similar pattern emerged with the end of year assessment. Presenting and writing skills were considered lacking and needing intervention rather than more traditional library skills in locating and retrieving information.

At the end of the survey the students were asked directly to answer which research skills they would appreciate further training in. These skill sets were not assessment dependent and drew widely from all aspects of the research process and some non-traditional library interventions. Popular training included refresher in academic writing $((59 \%)$ raising your research profile $(57 \%)$ and getting published (57\%). When asked why they would make these types of training a priority, the students articulated a range of perceived inadequacies. Academic writing was deemed a necessity throughout the PhD process and so continually relevant. Concerns from overseas students regarding their English language and worries by domestic students over their academic writing capabilities were also conveyed. One student was submitting a PhD through published work and believed publishing/ writing to be of particular relevance. The "Perennial paranoia" of worrying about missed research papers in the literature review, and anxiety about not utilising social media were also stated.

The preferred method of training from the library was online sessions $(24 \%)$, followed by one-to-one meetings with subject librarians (22\%) and interactive workshops on specific skills (19\%). The respondents conveyed a belief that interventions needed to be tailored to personal requirements and concerns about being time-poor were stated. When asked to comment further, there was a declared frustration with the lack of 'proper' library induction. One doctoral student stated that, "although we are more familiar with the library now than as an undergraduate, our needs have changed so a tailored induction would be welcomed". This initiative was echoed by another student who believed that there was a fundamental lack of awareness of library services and what the library had to offer. Another mentioned that short courses in information gathering were insufficient, as they felt that information gathering was a difficult skill to acquire.

\section{Social media and current awareness}

Although technological advances have changed the research landscape indefinably in the last number of years, an overwhelming amount of students did not use social media or apps to gather, store, manage or disseminate their research (74\%). Of the $26 \%$ that did use social media for research, Twitter proved the most popular choice. When asked about current awareness tools used, $37 \%$ used social media as a means of current awareness (i.e. setting up and managing alerts etc.). Interviewee $\mathrm{C}$, who used Twitter for current awareness, was retweeting as a form of self-archiving. Researchers of Tomorrow (British Library and JISC, 2012) found a low over all usage of web 2.0 technologies. It found that lack of acceptance of new tools for their research was not due to the lack of skills; evidence shows that it is more likely to be because the students did not see the immediate usefulness to their research. There is clearly an emergent role here for the academic library.

\section{Developing relationships between doctoral students and the library}


When questioned about attendance at library training, 74\% had attended a library induction or welcome and $68 \%$ had attended RefWorks training (13\% had attended no library training at all since beginning their studies). Of those that did attend some library training, $91 \%$ found the experience useful citing the library staff as supportive and helpful.

For those who had not attended library-led interventions, $40 \%$ believed that they did not require further training. Reasoning for this was that online training was sufficient for their needs and their supervisor provided all the support they needed. Twenty percent were unaware of the library training that was available.

A surprising amount of students (57\%) sought library assistance quite regularly (at least once a semester), and $73 \%$ of students had either met personally or spoken online with their subject librarian. Of those that had not, the general reason was that either they were unaware there was a subject librarian for them or that they just had not needed to use their subject librarian to date.

In relation to what the library could do to develop its relationship with researcher students, more interaction was seen as important, for example, through a dedicated researcher space, by providing more information on library facilities and services, more personal contact with a specific point of contact, or 'keep in touch' sessions.

\section{The relationship between profile and needs}

We have already established that training should be sharper and more focused on specialist needs and practices, but as a means of securing relationships with doctoral students, should we consider their profile at induction when assessing their needs? Should we be providing appropriate level and focus of library instruction and support for new research students based upon information that identifies incoming strengths and deficiencies (Munroe-Gulick and Petr, 2012)?

Interviewee A had cemented a relationship with her subject librarian during her Masters studies and found her $\mathrm{PhD}$ to be an extension of that relationship yet was unaware that she had a corresponding subject librarian on her nearest campus of the university, who she could physically visit if necessary. Interviewee $\mathrm{C}$, while coming from an information background, still harboured library anxieties and an apparent need to project self-efficacy, i.e. there was a concern or perception that looking for library assistance would be deemed unprofessional by her supervisor.

Interviewee B was an overseas candidate. While he had plenty of research experience and knowledge, he lacked library skills having studied elsewhere and needed a more localised knowledge. He criticised the lack of library outreach to overseas students, revealing that he did not even know what his borrowing capabilities were and this was his motivation in aiding the study - so that overseas students could benefit from new, targeted services.

Seventeen percent of the respondents were overseas students from a wide geographical area. Of those overseas students the majority articulated either unfamiliarity with library 
facilities or that lack of training was the main constraint in their research. This misalignment of services must be prioritised due to increasing internationalisation in the university sector.

What is apparent from the research is a fundamental need to communicate better with doctoral students and advocate better outreach. An environment of collaboration needs to be cultivated, whereby the student is bolstered by a team of professionals including library, ICT and faculty staff.

\section{Conclusions and recommendations}

The study clearly demonstrated that doctoral researchers value the library service and rely heavily on its online content. The study provides a snapshot of how the library is perceived as well as recommendations and opportunities for library growth and improvements in research support.

Lack of awareness of library resources and services is universal and perennial: facilities and services need to be actively and continually marketed to graduate students through their supervisors for authority and credibility. The optimal time to reach new PhD students is not the first week of the semester as these students arrive intermittently throughout the year. Embedding information literacy training in research support is essential for research students. Confronting an awareness of their information literacy skills deficiencies is essential to providing rationale for attendance. The library cannot assume that all graduates have had library or information training as diversity among the population is great with a considerable amount of doctoral non-digital natives and having a significant scholarly absence, or having undergraduate or other graduate experience elsewhere. There is also an explicit need to create training in non-traditional library services such as academic writing and using web 2.0 technologies for research.

A growing and poorly understood subset of graduate students is international students, who may be unfamiliar with the research library and have differing notions on academic integrity and plagiarism. These students should be targeted personally for library assistance and regular 'keep in touch' sessions.

Collaboration with supervisors and other University agencies is vital in cementing research students' acceptance of librarians' expertise. Supervisors play a critical role in the lives of the students and acknowledgement by faculty of the librarians' role in research is vital.

A doctoral 'Commons' would help alleviate first year self-efficacy and in turn have a positive effect on training attendance. The space could be used for cross-departmental training and if first year researcher students are aware of seasoned researchers attending library-led CPD courses they might be more likely to attend. Other research commons services could include consultation and training, and the provision of software. Examples have been staffed and managed in partnership with other campus units (Jaguszewski \& Williams 2013).

Dedicated graduate support areas which are inclusive of all services and facilities would be beneficial to postgraduates. These facilities could provide training by the library, ICT and other departments in collaboration in order to facilitate research excellence. Library 
interventions could be provided in all aspects of the research lifecycle from commencing a literature search to support for writing for publication. A facility such as this would counter researcher isolation, help raise researchers' profiles and overcome the self-efficacy that graduates project. Library interventions could be facilitated here while overcoming the previously discussed barriers to engagement with a physical library.

This research provides evidence of how first year doctoral students currently consider and use Ulster University library service. While their regard for the library is undiminished, their use of the physical library and its services is in decline. The academic library is at a turning point. Despite continuing challenges and budgetary constraints, the library does well to support researchers and research students. By embracing emergent roles in e-research support, librarians will be in a position to improve current provision and support to doctoral students and to future-proof their academic library services.

\section{Acknowledgements}

The authors were the recipients of the Maynooth University Library/New Review of Academic Librarianship Award for Academic Writing sponsored by Taylor \& Francis $2016 / 2017$. This article is the outcome of that winning proposal and the authors would like to thank the organisers, judges, and sponsors for recognising their work in making this award. The authors would also like to acknowledge the valuable feedback from Helen Fallon, prior to the submission of the article to the journal, and to thank Janet Peden, University Librarian at Ulster University for reading the revised article prior to its submission.

\section{References}

Allan, Barbara. (2010) Supporting Research Students, London: Facet Publishing.

Andretta, Susie. (2012) Ways of experiencing information literacy: Making a case for a relational approach, Oxford: Chandos.

Auckland, M. (2012). Re-Skilling for Research: An Investigation into the Role and Skills of Subject and Liaison Librarians Required to Effectively Support the Evolving Information Needs of Researchers. Research Libraries UK. Available at: http://www.rluk.ac.uk/wp-content/uploads/2014/02/RLUK-Re-skilling.pdf (accessed 6 Marhc 2017)

Badke, William B. (2012) Teaching Research Processes: The faculty role in the development of skilled student researchers, Oxford: Chandos.

Barrett, A. (2005). The information-seeking habits of graduate student researchers in the humanities, The Journal of Academic Librarianship, 31 (4): 324-331.

Bishop, C. G. (2015). An investigation of the information practices of education doctoral students. PhD dissertation, College of Education and Human Performance, University of Central Florida. Available at: 
http://etd.fcla.edu/CF/CFE0005580/CorinneBishopDissertation_Final_4-22-15.pdf (accessed 6 March 2017).

Blummer, B. (2009). Providing library instruction to graduate students: a review of the literature, Public Services Quarterly, 5 (1): 15-39.

Bøyum, I. \& Aabø, S. (2015). The information practices of Business PhD students, New Library World, 116 (3/4): 187-200.

British Library \& JISC (2012). Researchers of tomorrow: the research behaviour of Generation Y doctoral students. Available at:

http://www.jisc.ac.uk/media/documents/publications/reports/2012/Researchers-of-

Tomorrow.pdf (accessed 6 March 2017)

Bury, S. (2011) Faculty attitudes, perceptions and experiences of information literacy: a study across multiple disciplines at York University, Canada, Journal of information literacy, 5 (1): 45-64.

Bussell, H., Hagman, J. \& Guder, C. S. (2016) Research Needs and Learning Format Preferences of Graduate Students at a Large Public University: An Exploratory Study. College and Research Libraries. Pre-print available at:

http://crl.acrl.org/content/early/2016/12/22/crl16-1015.full.pdf.

Carpenter, J. (2012). Researchers of Tomorrow: The research behaviour of Generation Y doctoral students, Information Services and Use, 3 (2): 3-17.

Catalano, A. (2010) Using ACRL standards to assess the information literacy of graduate students in an education program, Evidence-Based Library and Information Practice, 5 (4). Available at: http://ejournals.library.ualberta.ca/index.php/EBLIP/article/view/8878 (accessed 6 March 2017).

Catalano, A. (2013). Patterns of graduate students' information seeking behavior: a metasynthesis of the literature, Journal of Documentation, 69 (2): 243-274.

Corrall, Sheila (2008) Information Literacy strategy in Higher Education: An exploratory study, International Journal of information management, 28 (1): 26-37.

Corrall, S. M. (2012). Changes in Academic Libraries: Evolution and Innovation in Research Support Services. In: Libraries in the Digital Age (LIDA) Conference, Part I: Changes in the World of Library Services: Evolution and Innovation, 18-20 June, 2012, Zadar, Croatia. Available at: http://ozk.unizd.hr/proceedings/index.php/lida2012/article/viewFile/74/45 (accessed 6 March 2017).

Cothran, T. (2011) Google Scholar acceptance and use among graduate students: A quantitative study, Library and Information Science Research, 33(4): 293-301.

Daland, H. (2013). The Ph.D. candidate as an information literate resource: developing research support and information literacy skills in an informal setting, Liber Quarterly, 23 (2): 134-155. 
Delaney, G. (2015). The perceptions, use and requirements of the academic library service at the University of Ulster among first year doctoral students. MSc Dissertation, MSc in Library and Information Management, School of Education, Ulster University.

Delaney, G. \& Bates, J. (2015). Envisioning the academic library: a reflection on roles, relevancy and relationships, New Review of Academic Librarianship, 21 (1): 30-51.

Dowling, R. \& Wilson M. (2017). Digital doctorates? An exploratory study of PhD candidates' use of online tools. Innovations in Education and Teaching International, 54 (1): 76-86.

Drachen, T. M., Larsen, A. V., Gullbekk, E. \& Westbye, W. (2011). Information behaviour and practices of PhD students. Available at: https://hal-hprints.archives-ouvertes.fr/hprints00599034/file/Information_behaviour_and_practices_of_PhD_students.pdf (accessed 6 March 2017).

Fleming-May, R. \& Yuro, L. (2009). From student to scholar: the Academic library and social sciences PhD students' transformation, Libraries and the Academy, 9(2): 199-221.

George, C., Bright, A., Hurlbert, T., Linke, E.C., St. Clair, G. \& Stein, J. (2006) Scholarly use of information: graduate students' information seeking behaviour, Information Research, 11(4),paper 272.

Available at: http://www.informationr.net/ir/11-4/paper272.html (accessed 6 March 2017).

Gibbs, D., Boettcher, J, Hollingsworth, J. \& Slania, H. (2012) Assessing the research needs of graduate students at Georgetown University, Journal of Academic Librarianship, 38 (5): 268-276.

Green, Rosemary (2010) Information illiteracy: examining our assumptions, Journal of Academic Librarianship, 36 (4): 131-319.

Green, R. \& Macauley, P. (2007). Doctoral students' engagement with information: An American Australian perspective, Libraries and The Academy, 7 (3): 317-332.

Harrington, M. R. (2009). Information Literacy and Research-Intensive Graduate students: Enhancing the Role of the Research Librarians, Behavioral \& Social Sciences Librarian, 28 (4): 179-201.

Harris, S. (2011). The case for partnering doctoral students with librarians: a synthesis of the literatures. Library Review, 60 (7): 599-620.

Hernon, P. \& Mathews, J. R. (2013) Reflecting on the Future of Academic and Public Libraries. American Library Association.

Housewright, R., Schonfeld, R. C. \& Wulfson, K. (2013) Ithaka S+R, Jisc and RLUK: UK Survey of Academics 2012. Available at:

http://repository.jisc.ac.uk/5209/1/UK_Survey_of_Academics_2012_FINAL.pdf (accessed 6 March 2017)

Jackson, C. (2013). Confidence as an indicator of research students' ability in IL: a mismatch, Journal of Information Literacy, 7 (2): 149-152. 
Jaguszewski, J. M. \& Williams, K. (2013). New Roles for New Times: Transforming Liaison Roles in Research Libraries. Report Prepared for the Association of Research Libraries.

Available at:

http://www.arl.org/storage/documents/publications/nrnt-liaison-roles-revised.pdf (accessed 6 March 2017).

Jubb, M. \& MacColl J. (2011) Supporting research: Libraries, administration and environments. Dublin OH: OCLC Research. Available at:

http://files.eric.ed.gov/fulltext/ED522674.pdf (accessed 6 March 2017).

Korobili, S, Malliari, A \& Zapoundidou, S. (2011) Factors that influence information-seeking behaviour: The case of Greek graduate students, Journal of Academic Librarianship, 37 (2): 155-165.

Kroll, S. \& Forsman R. (2010) A Slice of Research Life: Information Support for research in the United States. Dublin, OH: OCLC Research. Available at:

http://www.oclc.org/content/dam/research/publications/library/2010/201015.pdf?urlm=162948 (accessed 6 March 2017).

Kuhlthau, C. C. (1994). Students and the information search process: Zones of intervention for librarians. Advances in librarianship, 18: 57-72.

Liu, G. \& Winn, D. (2009) Chinese Graduate Students and the Canadian Academic Library: A User Study at the University of Windsor. Journal of Academic Librarianship, 35 (6): 565573.

Madden, R. (2014). Information behaviour of humanities PhDs on an information literacy course. Reference Services Review, 42 (1): 90-107.

Monroe-Gulick, A. \& Petr, J. (2012) Incoming Graduates in the Social Sciences: How much do they really know about Library Research? Libraries and the Academy, 12 (3): 315-335.

Patterson, A. (2009) A needs analysis in information literacy provision research: A case study in UCD, Journal of Information Literacy, 3 (1): 5-18. Available at: http://ojs.lboro.ac.uk/ojs/index.php/JIL/article/viewFile/PRA-V3-I1-2009-1/227 (accessed 6 March 2017).

Petch, M., Fraser, K., Rush, N., Cope, A. \& Lowe, J. (2016) Improving Communication Between Postgraduate Researchers and the University Library: A Case Study at De Montfort University Library and Learning Services, New Review of Academic Librarianship, 22 (2-3): 268-281.

Rempel H. (2010) A Longitudinal Assessment of Graduate Student Research Behaviour and the Impact of Attending a Library Literature Review Workshop. College and Research Libraries, 71 (6): 532-547.

Research Information Network (2011) The role of research supervisors in information literacy. A Research Information Network (RIN) Report. Available at: http://www.rin.ac.uk/system/files/attachments/Research_supervisors_report_for_screen.pdf (accessed 6 March 2017). 
Research Information Network (RIN) \& Research Libraries UK (RLUK) (2011) The value of libraries for research and researchers. London: Research Information Network. Available at: http://www.rluk.ac.uk/wp-content/uploads/2014/02/Value-of-Libraries-report.pdf (accessed 6 March 2017).

Sadler, E. \& Given, L.M. (2007). Affordance theory: a framework for graduate students' information behavior. Journal of Documentation, 63 (1): 115-141.

Secker, J. \& Macrea-Gibson, R. (2011) Evaluating M15102: an information literacy course for PhD students. Library Review, 60 (2): 96-107

Spezi, V. (2016) Is Information-Seeking Behavior of Doctoral Students Changing?: A Review of the Literature (2010-2015), New Review of Academic Librarianship, 22 (1): 78-106.

Špiranec, S. \& Zorica, M. B. (2012). Changing anatomies of Information Literacy at the postgraduate level: refinements of models and shifts in assessment. Nordic Journal of Information Literacy in Higher Education, 4 (1): 3-15.

Thomas, J. A. (2010) Future-proofing: the academic library's role in e-research support. In: Proceedings of Academic Librarian 2: Singing in the Rain: Conference towards Future Possibilities, 11-12 March, 2010, Hong Kong Polytechnic University, Hong Kong. Available at: http://eprints.qut.edu.au/31647/1/c31647.pdf (accessed 6 March 2017).

Vezzosi, M. (2009) Doctoral students' information behaviour: an exploratory study at the University of Parma (Italy), New Library World, 110 (1/2): 65-80.

Vitae (2010) The Vitae Researcher Development Statement. Available at: https://www.vitae.ac.uk/researchers-professional-development/about-the-vitae-researcherdevelopment-framework/the-vitae-researcher-development-statement (accessed 6 March 2017). 


\section{Appendix: Survey questions}

1. Which graduate school do you attend?

- Faculty of Arts

- Faculty of Art, Design and the Built Environment

- Faculty of Computing and Engineering

- Faculty of Life and Health Sciences

- Faculty of Social Sciences

- Ulster Business School

2. What is your $\mathrm{PhD}$ topic/Area of study?

3. Are you studying part-time or full-time?

4. Which category includes your age?

- $18-25$

- $26-40$

- $40+$

5. Are you male or female?

6. Is English your first language?

7. What has been you academic route to PhD Study?

- Direct from Postgraduate study at Ulster University

- $\quad$ Direct from Undergraduate study at Ulster University

- Direct from Postgraduate study at another institution

- Direct from Undergraduate study at another institution

- After a long scholarly absence (more than three years)

- As an extension of my professional work

- Other

8. When was your last piece of academic writing before your $\mathrm{PhD}$ proposal?

- 0-6 months

- 7-11 months

- 1-3 years

- 4-9 years

- $10+$ years

9. In which of the skills listed below do you feel additional training might have been/could be useful for your 100 days Viva/Initial Assessment? Please choose any that apply.

- Presenting skills

- Academic writing

- $\quad$ Generic computer skills such as using PowerPoint/Prezi

- Locating and retrieving information

- Using Information management tools

- RefWorks/referencing

- Finding thesis/conference proceedings

- Using web 2.0 for research

- Locating and using primary sources

- Writing a literature review

- Current awareness training

- A consultation with a subject librarian

- I do not need further training 
10. For your end of year Annual Report/Assessment which THREE skills do you feel you could use further training in?

- Presenting skills

- Academic writing

- $\quad$ Generic computer skills such as using PowerPoint/Prezi

- Locating and retrieving information

- Using Information management tools

- RefWorks/referencing

- Finding thesis/conference proceedings

- Using web 2.0 for research

- Locating and using primary sources

- Writing a literature review

- Current awareness training

- Other

11. What do you consider to be your main 'go-to' resource when finding information for your research? Please choose one.

- Browsing the library shelves

- Wikipedia

- Guides to catalogues of archival material

- Citation databases

- $\quad$ Subject-specific information gateways (LibGuides)

- Website of person/organisation

- Bibliographic database

- Search interface of e-journals

- Cross-institutional library catalogue (COPAC)

- Library Catalogue

- Google

- Google Scholar

- Other

12. Why do you prefer this information source above others?

13. What type of information source do you use most frequently? Please choose one.

- Sound/video recording

- Raw data

- Printed photograph or other digital image

- News article (print or online)

- Published data

- Databases

- Newspapers

- Digitised versions of manuscripts/archival projects

- E-Book

- Abstract, bibliographic reference

- Printed Journal

- Printed Book

- Full text e-journal

- Other

14. Which tools do you use for keeping up to date with research on your subject? Please tick all that apply.

- Social media (Twitter/ Facebook/ Blogs etc.)

- Current awareness alerts (Google alerts/ Journal alerts/ Conference alerts etc.)

- Discussion Lists (JiscMail/ CataList etc.)

- Library Resources (Researchers' Blog/ LibGuides etc.) 
- None

- Other

15. Which current awareness alerts, from those listed in Q14, is the most useful to you and why?

16. Do you use social media or apps to gather, store, manage or disseminate your research?

17. Do you require access to primary sources for your research (original print /maps/music/data sets etc.)?

18. How do you rate your competency in the following information skills? (no familiarity, not confident, fairly confident or very confident)

- Bibliography compiling

- Reference citing

- Information finding- Using databases, journals and other

- library resources

- Academic Writing

- Use of citation indexes to trace articles

- Using e-books

- Copyright and Intellectual Property Issues

- Finding Thesis/Conference papers

- Generic Computer Skills

- Finding external research resources

- Keeping up to date with research (current awareness

- training)

- Using web 2.0 technologies to support your research

- Training in applications that might ease your workflow and research process (Google Scholar etc.)

- Plagiarism and academic integrity

- Finding 'Grey Literature' like Government papers and Official

- Publications

- Use of Search Engines

- Use of Advanced Options in search engines

- Evaluation of websites

19. Hodkinson, P. (2011) Ageing in a spectacular 'youth culture': Continuity, and community among older Goths. British Journal of Sociology. 62 (2), 262-282 what type of reference is this?

- A Book

- An Article in a Journal

- A Chapter in Book

20. Liston, K. (2002)The Gendered Field of Irish Sport. In: Corcoron, M. and Peillon, M.(eds) Ireland Unbound: A Turn of the century chronicle. Dublin: IPA, 231-246. What type of reference is this?

- A Book

- An Article in a Journal

- A Chapter in a Book

21. DeLashmutt, M.W.2004. Augustine's quest for the self: a threefold journey. Esharp [online] 1. Available at: http://www.sharp.arts.gla.ac.uk/esharp/articles/spring_2004/Michael_DeLashmuttAugustines_Quest.htm [Accessed: 10 June 2004]. What is this citation for?

- A Website

- An online journal article

- A Blog post

- A Thesis 
22. Robinson, N. (2011) No end insight for Eurozone crisis. Nick Robinson's newslog.4 November. Available from:http://www.bbc.co.uk/blogs/nickrobinson/[Accessed 10 October 2011]. What is this a reference to?

- A Blog

- An online thesis

- A Tweet

- An Online conference paper

23. Which ONE answer is NOT a form of plagiarism?

- Copy and pasting from a paragraph of text from a website without enclosing it in quotation marks and referencing the

- source

- Using the ideas from another author without providing a reference, even if you write it in your own words

- Copying and pasting a diagram or table from a website and providing a reference for the source underneath

- Self-plagiarism

24. Which ONE of these statements about e-books is FALSE?

- E-books can be accessed and used off campus

- Downloadable e-books can be downloaded to most devices

- Access is completely denied to a reader for a book that has previously been downloaded

- The lending period for a downloadable e-book is three days

25. Are you aware of, or have you ever used the campus library's Special Collections?

26. Have you ever used your library to facilitate access to resources from other libraries?

27. What do you believe to be the main constraint on your research information skills? Please choose one.

- Licensing restrictions/limitations imposed by electronic devices

- Off campus access difficulties

- $\quad$ Lack of training

- Difficulty identifying/accessing relevant research material

- Lack of your own information-seeking/research skills

- Location of your main place of study

- No constraints so far

- Other

28. Where is your principal place of study? Please choose one.

- Office in the University

- Lab or studio in the University

- At Home

- The University Library

- Another Library

- Another place

29. Why do you prefer to study here?

30. What Library Training have you attended during your doctoral studies? Please tick all that apply.

- Library Induction/Welcome

- RefWorks

- Harvard Referencing

- Subject Class with subject librarian

- Drop-in Session

- None 
- Other (please specify)

31. If you have attended library training do you think it was useful?

32. If you have not attended any library training why is this? Please tick all that apply.

- The online training is sufficient for my needs

- The Graduate Research training is sufficient for my needs

- I do not need further research training

- I was unaware that there was library training available

- I don't think I should be bothering the librarians

- I am uncomfortable in the library

- I feel that I should now be self-sufficient in my research

- I get all my help from my supervisor

- The librarians cannot provide the subject expertise I need

- Other

33. What stops you from using the campus library and physical resources more? Please tick all that apply.

- Lack of dedicated researcher space

- Unfamiliarity with library

- Unfamiliarity with subject librarian

- Everything I need is online

- Environmental issues in the library (Noise/Temperature etc.)

- Space and storage constraints

- The library does not provide the subject expertise that I need

- Other

34. How often would you seek library assistance with your research needs? Please tick one.

- Often (More than once a semester)

- Regularly (About once a semester)

- Not regularly (Less than once a semester)

- Never

35. Have you ever met with your Subject Librarian, either personally or spoken online?

36. How might the library develop its relationship with you as a researcher?

37. Which library resource do you consider critical to your work? Please choose THREE.

- Online journals

- Print journals

- E-Books

- Print Books

- Subject Librarian Support

- Digitised Resources

- Primary Resources

- Bibliographic software training (RefWorks)

- Information skills training

- Access to other libraries and their resources

- Purchasing capabilities

- Availability of study space

- Library Researchers' Blog

38. How important do you think these library resources are to you and your research? (where 0 is not important and 5 is very important)

- Inter-library Loan

- Inter-campus loan 
- Library's printed collections

- Library's online resources

- Library's access to other libraries

- Library's funding for travel to other libraries

- RefWorks/ Bibliographic training

- Information Skills training

- Library space for study

- Subject Librarian Support

- Research Support Pages

39. Which Research Skills would you welcome further training in? Please tick all that apply.

- Refresher in academic writing

- Specific information skills ( finding grey literature/ using specific services and tools)

- Referencing/bibliographic Training

- $\quad$ Finding/Using specific subject based resources

- Generic Computer Skills

- Finding external research resources

- Keeping up to date with research (current awareness training)

- $\quad$ Finding/Using archival resources

- Open access publishing/self-archiving

- Using web 2.0 technologies to support your research

- Copyright and intellectual property rights and research

- Publishing

- Training in applications that might ease your workflow and research process (Google Scholar etc.)

- Plagiarism and academic integrity

- Raising your research profile

40. Which training, from the list above, would you make it a priority to attend and why?

41. What would be your preferred method of Research Skills training from the library? Please choose one.

- $\quad$ Printed Guides

- Online workshops/tutorials

- Library Induction

- One-to-one sessions with Subject Librarian

- Drop-in clinics for your Graduate School

- Interactive Workshops covering specific skills/resources

- Other

42. Please assess the following: (strongly agree / agree / neutral / disagree / strongly disagree)

- The University Library (including the online library) is essential to my PhD research

- I I am able to find any information I need through the University Library (including the online library)

43. How often do you visit the library?

- Every day

- Weekly

- Monthly

- Rarely

- Never

44. How often do you access the Library online?

- Regularly (a few times a day)

- Often ( a few times a week)

- Sometimes (a few times a month)

- Rarely

- Never 
45. Please feel free to comment on any further training or services that you would like to see the library facilitate or any services you feel have supported your studies to date.

46. What has been the University library's role in your research to date, if any?

47. Is there anything else you would like to add? 